\section{Critical Instrumentation Area: Influence of Root Canal Anatomy on the Endodontic Preparation}

\author{
Maria Antonieta Veloso Carvalho de Oliveira1, Jessyca Figueira Venâncio', \\ Analice Giovani Pereira1 , Luís Henrique Araújo Raposo², João Carlos Gabrielli \\ Biffi $^{1}$
}

'Department of Endodontics, School of Dentistry, UFU - Federal University of Uberlândia, MG, Brazil ${ }^{2}$ Department of Occlusion, Fixed Prosthodontics and Dental Materials, UFU - Federal University of Uberlândia, MG, Brazil

Correspondence: João C. G. Biffi, Avenida Pará 1720, Campus Umuarama, Bloco 4L, Sala 4LA28, 38400-902 Uberlândia, MG, Brasil. Tel: +55-34-32182209. e-mail: jcgbiffi@ufu.br
The aim of this study was to evaluate the root canal anatomy of mandibular incisors before and after endodontic instrumentation, identifying regions inaccessible to the action of files (Critical instrumentation Area - CA) in a three-dimensional perspective. Thirty human mandibular central incisors were selected, assigned to two groups $(n=15)$ and instrumented using ProTaper Universal rotary files. In the RX group, longitudinal digital radiographic images were obtained in the buccolingual $(\mathrm{BL})$ and mesiodistal (MD) views. In the CT group, cross-sectional micro-computed tomography $(\mu \mathrm{CT})$ images were obtained at 3,9 and $15 \mathrm{~mm}$ from the apex. The canal area of the specimens was evaluated before and after instrumentation using digital images from each group. Data were analyzed using t-test, one-way ANOVA with subdivided parcels and Tukey's test $(\alpha=0.05)$. The canal area found in the MD radiographs was larger than in the BL radiographs, which was also confirmed in the transversal images $(p<0.01)$. The CA was only detected in the MD radiographs and $\mu \mathrm{CT}$ scans. On the root canal configuration, a continuous reduction in the canal conicity was observed in BL radiographs, while in MD view there was a constriction at the cervical third and subsequent increase at the middle third $(p<0.01)$. The conical shape of the root canal was observed only in the BL view. The canal enlargement in BL radiographs was not indicative of homogeneous instrumentation, since unprepared areas (CA) were also verified on the buccal and lingual walls in different images.

\author{
Key Words: micro-computed \\ tomography, critical \\ instrumentation area, digital \\ radiography, endodontic \\ preparation, root canal anatomy.
}

\section{Introduction}

Anatomical complexities may characterize physical barriers that prevent adequate disinfection of root canals (1). This is one of the main reasons why it is not possible to assure adequate endodontic treatment for teeth without a thorough knowledge of the internal details of root anatomy (2). Root canals should be analyzed in a three-dimensional perspective; however, the conventional radiographic images usually available in clinical practice, allow only two-dimensional visualization of teeth.

The anatomical variations become even more evident when studying teeth in buccolingual $(\mathrm{BL})$ and mesiodistal (MD) views (2-7). The number of root canals (3), canal diameter (4) and dentin thickness at the apical third (2), become increased in the MD view. The root canal configuration and curvature angle before and after endodontic instrumentation also differ when compared in $\mathrm{BL}$ and $\mathrm{MD}$ views (5).

Dental images obtained clinically with BL radiographs provide only partial information about the root canal morphology (5). This frequently leads to misinterpretation on the access of files to the root canal walls. When observing teeth in the MD view, it is possible to realize the limitations of root anatomy to the action of files during instrumentation on the buccal and lingual walls in the full canal extension (8). In this way, it is also possible to detect areas where anatomical interferences can affect the action of files, which were designated in the present study as Critical instrumentation Area (CA). CA represents the unprepared regions observed in some studies that compared the efficacy of different endodontic instruments $(7,9)$ and may correspond up to $42 \%$ of the total canal area in some cases (7), and to $53 \%$ of the apical third (9).

The inability of endodontic instruments in fully cleaning root canals became more evident in studies that evaluated the cross-section of teeth after different instrumentation or retreatment techniques $(10,11)$, specially micro-computed tomograph $(\mu \mathrm{CT})$ images $(9,11-13)$. The self-adjusting file (SAF) system presents considerable advantages when compared to systems with round cross section files, such as homogenous and circumferential preparation of root canals (12). However, even these instruments do not completely clean all canal walls during the endodontic treatment $(9,12,14)$ or retreatment $(15)$.

Therefore, this study aimed to demonstrate that the critical instrumentation area can be influenced mainly by the root canal anatomy, using association of dental radiographs and micro-computed tomography, which may provide a non-invasive reproducible technique for qualitative and quantitative three-dimensional 
assessment of these parameters $(16,17)$. Thus, human mandibular incisors were evaluated before and after the instrumentation for identification of regions inaccessible to the action of files in a three-dimensional perspective using longitudinal images (digital radiographs) and transversal images ( $\mu$ CT scans).

\section{Material and Methods}

Thirty human mandibular central incisors were selected (gathered following an informed consent approved by the Committee for Ethics in Research of the Federal University of Uberlândia \# 174.003).

The selection criteria included single root canal presence and anatomical diameter of the apex compatible to \#20 K-file (Dentsply Maillefer, Ballaigues, Switzerland). Teeth presenting previous endodontic treatment, intraradicular posts, fractures or extensive crown damages were excluded from study. The specimens were assigned to two groups according to the image assessing method: $\mathrm{RX}$ - radiographed teeth; and CT - teeth scanned by $\mu \mathrm{CT}$. Next, the teeth were evaluated by each method before and after root instrumentation procedures.

Coronal opening was performed using round diamond burs (\#1016; KG Sorensen, Barueri, SP, Brazil) and tapered carbide burs with non-cutting tip (Endo-Z; Dentsply Maillefer), and the root canals were located and explored with a \#10 K-file (Dentsply Maillefer). The working length was determined subtracting $1 \mathrm{~mm}$ from the length measured when the tip of the file was first observed emerging from the apical foramen. Teeth were then instrumented with rotary files (ProTaper Universal; Dentsply Maillefer) up to F3 file, following the manufacturer's instructions. Each instrument was passively introduced into the root canals at a $300 \mathrm{rpm}$ rotation rate (X Smart; Dentsply Maillefer), with a 16:1 reduction handpiece and $2 \mathrm{~N} / \mathrm{cm}$ torque. Irrigation was performed with $1 \mathrm{~mL}$ of $1 \%$ sodium hypochlorite after each instrument.

For the RX group $(n=15)$, radiographs were taken before and after instrumentation in the buccolingual (BL) and mesiodistal (MD) views for each tooth, using an radiographic unit (Spectro 70X; Dabi Altlante, Ribeirão Preto, SP, Brazil) with 1.2 kVA output, 70kVP tube head and $8 \mathrm{~mA}$, coupled to a digital radiographic sensor (CDR 2000; Schick Technologies Inc., Long Island City, NY, USA). The exposure time was set to $0.25 \mathrm{~s}$ for each digital radiograph as recommended by the manufacturer. At last, additional radiographs of the teeth were taken in both views (BL and $\mathrm{MD}$ ) with the master apical file (F3) positioned in the root canal in order to identify and quantify the total canal area and the CA ( $n=15)$ (Fig. 1). Next, the path of the root canal walls was delimited digitally with lines and the total canal area was determined. The $\mathrm{CA}$ was considered as the region in which the anatomical interferences affected or prevented the action of files on the buccal and/or lingual canal walls and was also delimited digitally and measured (Fig. 1E).

The post-instrumentation radiographs taken without the master apical file were used to evaluate root canal configuration in the $\mathrm{BL}$ and $\mathrm{MD}$ views by determining four horizontal lines along the canal that corresponded to: 1coronal access; 2-cervical; 3 - middle; and 4- apical thirds
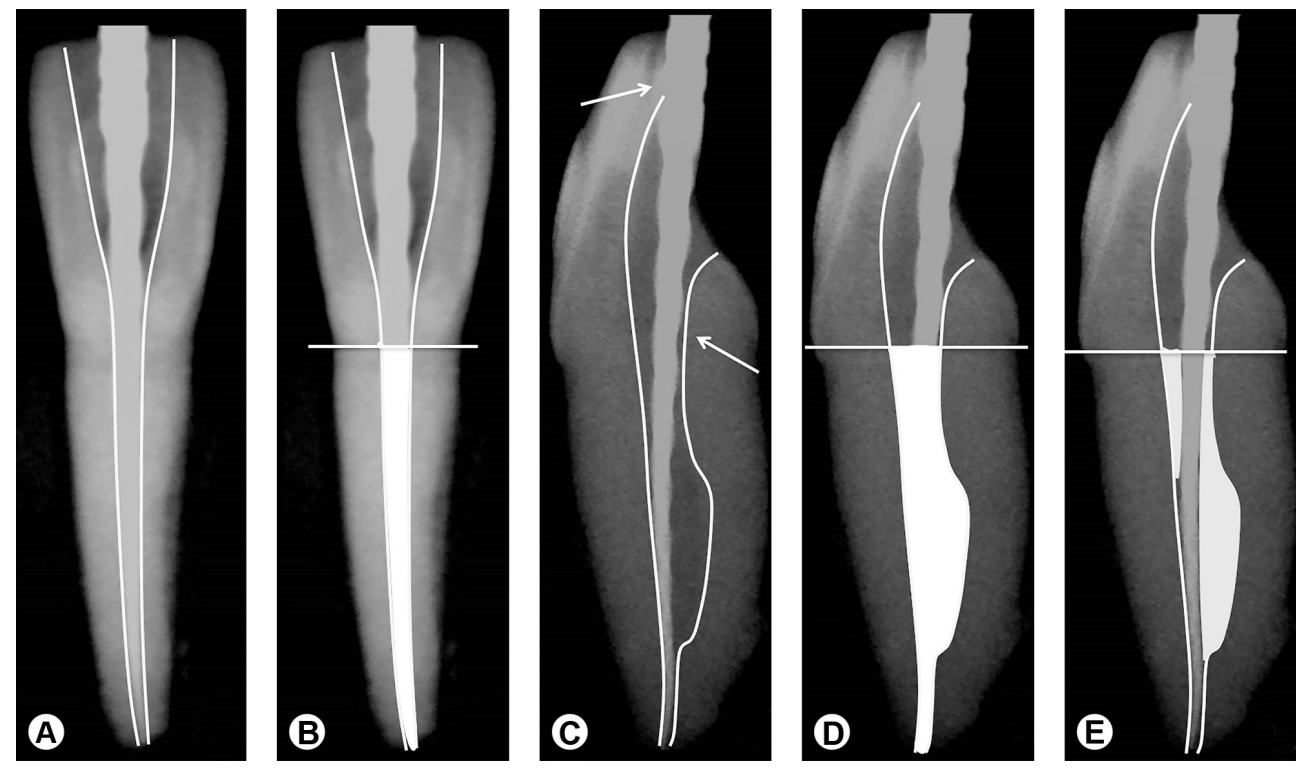

Figure 1. Determination of the total canal area and critical instrumentation area (CA). A: Marking lines on the canal walls in the buccolingual view (white lines). B: Total canal area in the buccolingual view (white area). C: Marking lines on the canal walls in the mesiodistal view (white lines; * white arrows show the anatomical interferences). D: Total canal area in the mesiodistal view (white area). E: CA in the mesiodistal view (grey area). 
(Figs. 2A and 2B). The measuring lines were standardized in the same position in the $\mathrm{BL}$ and $\mathrm{MD}$ radiographs. After, all measurements were performed using image processing and analysis software (ImageJ 1.46; NIH, Bethesda, MD, USA).

For the CT group $(n=15)$, the specimens were mounted in a custom attachment base and scanned before and after instrumentation using $\mu$ CT scanner (SkyScan 1172; Bruker-microCT, Kontich, Belgium) at an isotropic pixel size of $19.6 \mu \mathrm{m}, 90 \mathrm{kV}, 112 \mu \mathrm{A}$, resulting in the acquisition of 1000 transverse cross scans per tooth in each stage. The scanning procedure was carried out by $360^{\circ}$ rotation around the vertical axis; camera exposure time of $2600 \mathrm{~ms}$, rotation step of $0.6^{\circ}$, frame averaging of 2 and medium filtering of the data were applied. The total canal area was quantified before and after root instrumentation in transversal scans located at $3 \mathrm{~mm}$ (apical third), $9 \mathrm{~mm}$ (middle third), and $15 \mathrm{~mm}$ (cervical third) from the apex (Figs. 2C, 2D and 2E). The CA, the instrumented canal area and the area of dentin removed from the original canal path were also quantified after root instrumentation. All quantifications were performed using the scan software (CTAn 1.11.1.0; Bruker-microCT). Shapiro-Wilk and Levene tests in order to check for homoscedasticity. The results from the total canal area before and after instrumentation inside the groups were compared using paired t-test $(\alpha=0.05)$. The comparisons between groups were performed with t-test and one-way analysis of variance with subdivided parcels and Tukey's test. All the tests were performed at a 5\% level of significance with a statistical software package (SigmaPlot v.12.0; Systat Software Inc., Chicago, IL, USA).

\section{Results}

The mean measurements from the total canal area and $\mathrm{CA}$ obtained in the $\mathrm{BL}$ and $\mathrm{MD}$ radiographs are shown in Table 1. Larger root canal areas were observed in the MD radiographs, before and after the instrumentation. The total canal area increased after instrumentation in the $\mathrm{BL}$ $(p<0.001)$ and $M D(p=0.002)$ radiographs. CA was observed only in the MD radiographs, presenting lower values than the total canal area checked in this view $(p<0.01)$.

The mean measurements from the horizontal lines for the root canal configuration in both radiographic views are presented in Table 2. A conical shape of the canal with progressive reduction in the length of the measuring lines was observed in the $B L$ radiographs $(p<0.001)$, while the $M D$ radiographs presented increased length from measuring

Table 1. Mean values $\left(\mathrm{mm}^{2}\right)$ and standard deviations for the total canal area and critical instrumentation area (CA) in the buccolingual $(\mathrm{BL})$ and mesiodistal (MD) radiographic views before (b) and after (a) instrumentation in the RX group

\begin{tabular}{lc}
\hline Root canal region (radiographic view) & Mean value $\left(\mathrm{mm}^{2}\right)$ \\
\hline Total canal area (BL-b) & $4.33 \pm 1.15^{\mathrm{a}}$ \\
Total canal area (BL-a) & $7.89 \pm 1.82^{\mathrm{b}}$ \\
Total canal area (MD-b) & $13,37 \pm 2.82^{\mathrm{c}}$ \\
Total canal area (MD-a) & $14.66 \pm 2.87^{\mathrm{d}}$ \\
CA (BL) & 0 \\
CA (MD) & $9.41 \pm 2.52^{\mathrm{e}}$ \\
\hline
\end{tabular}

Different letters indicate statistically significant difference between rows $(\mathrm{p}<0.05)$.
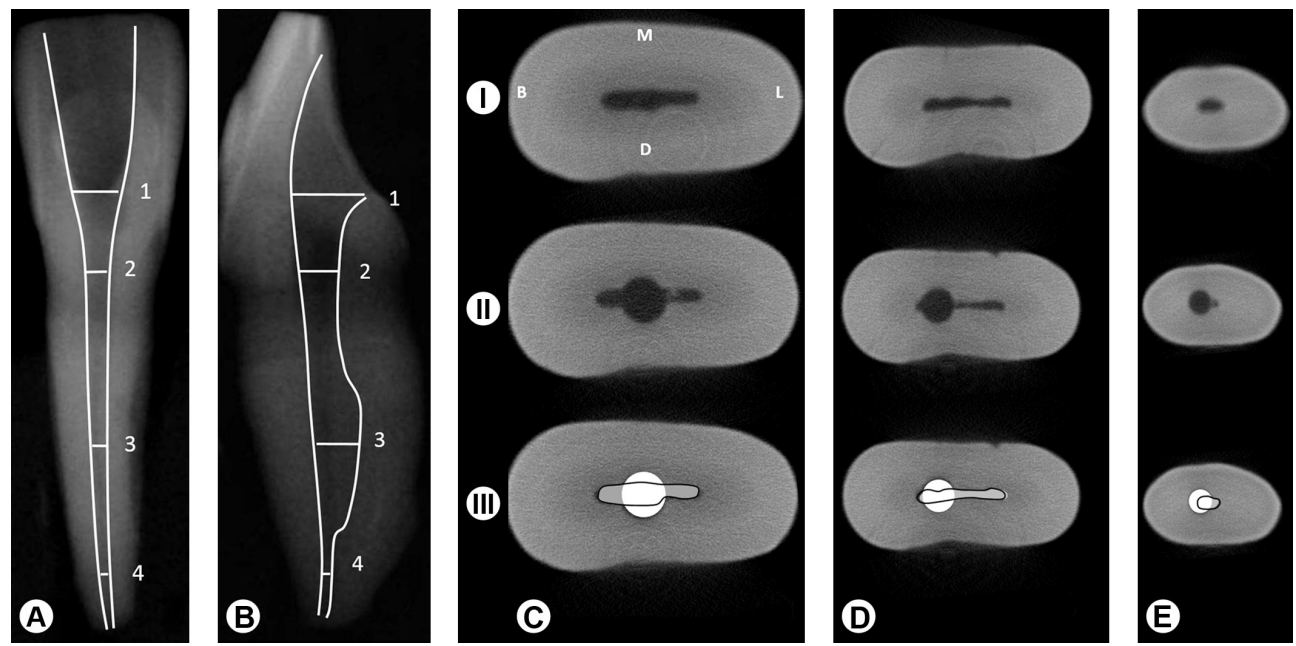

Figure 2. Evaluation of the root canal configuration by horizontal measuring lines traced through the canal, corresponding to coronal access (1), cervical third (2), middle third (3), apical third (4) in the buccolingual (A) and mesiodistal (B) radiographic views. Cross-sectional scans - Cervical third (C), middle third (D) and apical third (E). B, L, M and D stand for buccal, lingual, mesial and distal, respectively. From top to bottom: 1- before instrumentation; 1l- after instrumentation; 111- delimitation of CA (grey area), canal instrumentation area (white area), and original canal area (black line). 
lines 2 to $3(p<0.001)$, exhibiting irregular shape of the root canal. The measures obtained from the transversal scans from CT group are exhibited in Table 3. The total canal area was increased after instrumentation in all evaluated scans $(p<0.001)$. CA was observed following instrumentation in the $\mathrm{BL}$ direction, besides the dentin removal region off the original path of the canal in the MD direction (Fig. 2E).

\section{Discussion}

Different anatomical root canal configurations were verified in the radiographic views and the differences between the canal area observed in the $B L$ and MD views became more evident in the transversal scans obtained with the $\mu \mathrm{CT}$ analysis. Mandibular incisors exhibited flattened and oval canals when observed in the MD view, which represent a challenge to any file system $(8,9)$.

The unprepared areas corresponded to $64.2 \%$ of the total canal area observed in the MD radiographs. Comparing the specimens before and after instrumentation, the nonprepared area corresponded to $37.7 \%, 54.3 \%$ and $41.2 \%$ of the original total canal area in the cervical, middle and apical thirds, respectively. This was found on the buccal and/ or lingual canal walls, both in MD radiographs and $\mu \mathrm{CT}$ scans. Additionally, the transversal scans showed that actually the root canal enlargement was not homogeneously performed

Table 2. Mean values ( $\mathrm{mm}$ ) and standard deviations obtained at the four horizontal lines for the root canal configuration in the buccolingual (BL) and mesiodistal (MD) radiographic views for the RX group

\begin{tabular}{lcccc}
\hline \multirow{2}{*}{$\begin{array}{l}\text { Radiographic } \\
\text { view }\end{array}$} & \multicolumn{4}{c}{ Horizontal measuring lines $(\mathrm{mm})$} \\
\cline { 2 - 5 } & 1 & 2 & 3 & 4 \\
\hline Buccolingual & $1.71 \pm 0.21^{\mathrm{Ab}}$ & $1.01 \pm 0.15^{\mathrm{Bb}}$ & $0.56 \pm 0.14^{\mathrm{Cb}}$ & $0.28 \pm 0.1^{\mathrm{Db}}$ \\
Mesiodistal & $2.24 \pm 0.31^{\mathrm{Aa}}$ & $1.32 \pm 0.22^{\mathrm{Ca}}$ & $1.67 \pm 0.26^{\mathrm{Ba}}$ & $0.43 \pm 0.13^{\mathrm{Da}}$ \\
\hline
\end{tabular}

Measuring lines: 1- coronal access; 2- cervical third; 3- middle third; 4- apical third. *Capital letters indicate significant differences between columns; small letters indicate significant differences between rows $(p<0.05)$.

Table 3. Mean values $\left(\mathrm{mm}^{2}\right)$ and standard deviations for total canal area before (b) and after (a) instrumentation, critical instrumentation area (CA), canal instrumented area, and area of dentin removal off the original canal path in the $\mu \mathrm{CT}$ cross-sectional scans for the CT group.

\begin{tabular}{lccc}
\hline \multirow{2}{*}{ Measurement } & \multicolumn{3}{c}{ Root canal third } \\
\cline { 2 - 4 } & Cervical $\left(\mathrm{mm}^{2}\right)$ & Middle $\left(\mathrm{mm}^{2}\right)$ & Apical $\left(\mathrm{mm}^{2}\right)$ \\
\hline Total canal area (b) & $0.61 \pm 0.22^{\mathrm{a}}$ & $0.35 \pm 0.16^{\mathrm{a}}$ & $0.17 \pm 0.07^{\mathrm{a}}$ \\
Total canal area (a) & $1.19 \pm 0.22^{\mathrm{b}}$ & $0.72 \pm 0.19^{\mathrm{b}}$ & $0.40 \pm 0.16^{\mathrm{b}}$ \\
CA & $0.23 \pm 0.15$ & $0.19 \pm 0.09$ & $0.07 \pm 0.08$ \\
Canal instrumented area & $0.39 \pm 0.14$ & $0.17 \pm 0.08$ & $0.12 \pm 0.05$ \\
Dentin removal area & $0.57 \pm 0.25$ & $0.37 \pm 0.12$ & $0.22 \pm 0.09$ \\
\hline
\end{tabular}

Different letters indicate statistically significant difference between rows $(\mathrm{p}<0.05)$. along the entire canal area. While in $\mathrm{BL}$ view the root canal exhibited a post-instrumentation enlargement of almost twice its original size, $\mu \mathrm{CT}$ scans indicated that this enlargement occurred mainly in the MD direction.

Several studies have shown unprepared regions in the root canals, irrespective of the instrumentation technique or endodontic system used for treatment $(1,10,11,16,18,19)$ or retreatment $(13,20)$. The presence of non-prepared regions have been attributed to the oval or flattened anatomy of the root canals $(9-12,16,17,19,21)$. This is believed to occur mainly because of the reduced canal extension in the MD direction (10) over its increased extension in the BL direction (16). Others have justified the unprepared regions as resulting from limitations of the instrumentation technique (21), instrument taper (10) or file alloy properties (11).

From the results of the present study it became evident that the presence of non-prepared regions occurs due to the incompatibility between the file configuration and the root canal anatomy. The endodontic instruments and techniques are mostly designed to fit the conical configuration of the root canal usually observed in BL radiographs, thus ignoring the different canal configurations found in MD radiographs. In a MD view of the mandibular incisors, there is a constriction at the cervical third that could affect the action of files on the root canal walls, thus establishing critical instrumentation areas. Irrespective of the system, endodontic files are tapered, which results in conical preparations in root canals that mostly present a three-dimensional irregular configuration $(6,18)$. One solution would be to instrument canals with SAF, which can result in fewer unprepared areas during instrumentation (9), especially in the coronal root third (12). Some authors reported no differences for the percentage of instrumented area in the apical third when using NiTi and SAF rotary systems (12). However, the use of SAF generates more contact to the dentin walls in the apical third, consequently removing more debris (9). Presence of debris (smear layer) obliterating root canal was verified in the non-prepared areas with the $\mu \mathrm{CT}$ scans (Fig. 2C). This fact may influence the success of endodontic treatment, because bacterial film still remains organized at these sites $(1,22,23)$. Bacteria in the root canal biofilm may remain protected from the antimicrobial therapeutics when canal walls are not completely reached by endodontic instruments and irrigating solutions (23).

In order to minimize the difficulties due to the root canal anatomy, the authors suggest methods that provide active irrigation of the root canals, such as sonic vibration or negative pressure-based systems (24). Moreover, calcium hydroxide is also 
recommended as the intracanal medication of choice to be used between endodontic sessions, especially when treating necrotic pulps (22). Additional studies on endodontic techniques and instruments taking into consideration the MD configuration of the root canal are required to provide better instrumentation of all canal walls without leading to excessive wear and deviations.

The potential limitation of this study could also be a result of a relatively small sample size; however, this is common to other $\mu \mathrm{CT}$ studies $(9,16)$. Within this limitation, it may be concluded that the conical shape of the root canal was observed only in the BL view. In addition, the canal enlargement verified in this view was not indicative of homogeneous instrumentation, since non-prepared areas (CA) were observed in other images of the buccal and lingual root canal walls.

\section{Resumo}

Este estudo avaliou a anatomia do canal radicular de incisivos inferiores, antes e após a instrumentação endodôntica, identificando regiões inacessiveis à ação das limas (Área Crítica de instrumentação - AC), em uma perspectiva tridimensional. Trinta incisivos centrais inferiores humanos foram selecionados, divididos em dois grupos $(n=15)$, e instrumentados usando limas rotatórias ProTaper Universal. No grupo RX, imagens longitudinais foram obtidas em duas incidências, vestibulo-lingual (VL) e mésio-distal (MD), por meio de radiografias digitais. No grupo CT, imagens transversais foram obtidas por meio de microtomografia computadorizada ( $\mu \mathrm{TC})$, em secções localizadas a $3 \mathrm{~mm}, 9 \mathrm{~mm}$, e $15 \mathrm{~mm}$ do ápice. A área do canal das amostras foi avaliada antes e após a instrumentação usando as imagens digitais de cada grupo. Os dados foram analisados por meio do teste t, ANOVA a um critério com parcela subdividida e ao teste de $\checkmark$ Tukey $(\alpha=0,05)$. A área de canal encontrada nas radiografias MD foi maior do que nas radiografias $V L$, o que também foi confirmado nas imagens transversais $(p<0,01)$. A Área Crítica de instrumentação só foi detectada nas radiografias MD e nas seções de $\mu \mathrm{TC}$. Na configuração de canal, a redução contínua na conicidade do canal foi observada nas radiografias $V L$, enquanto na incidência $M D$, houve uma constrição no terço cervical e um subsequente aumento no terço médio $(p<0,01)$. A forma cônica do canal radicular foi observada somente na visão VL. 0 alargamento do canal verificado nas radiografias VL não foi indicativo de instrumentação homogênea, uma vez que áreas não instrumentadas (AC) foram observadas nas paredes vestibular e lingual em visões distintas.

\section{Acknowledgements}

The authors are indebted to Dr. Karla Vasconcelos and Dr. Frab Bóscolo from the Piracicaba School of Dentistry, University of Campinas (FOPUNICAMP) for the support with the radiographic images and to the Research Support Foundation of the State of Minas Gerais (FAPEMIG) for the financial support of the project.

\section{References}

1. Siqueira JF, Jr., Alves FR, Almeida BM, de Oliveira JC, Rôças IN. Ability of chemomechanical preparation with either rotary instruments or self-adjusting file to disinfect oval-shaped root canals. J Endod 2010;36:1860-1865.

2. Pineda $F$, Kuttler $Y$. Mesiodistal and buccolingual roentgenographic investigation of 7,275 root canals. Oral surg oral med oral pathol 1972;33:101-110.

3. Walker RT. Root form and canal anatomy of mandibular second molars in a southern Chinese population. J Endod 1988;14:325-329.
4. Eskoz N, Weine FS. Canal configuration of the mesiobuccal root of the maxillary second molar. Journal of Endodontics 1995;21:38-42.

5. Pereira AG, Santos RMF, Azevedo KCM, Raposo LH, Biffi JC. Assessment of influence of flexion angles of files in apical stop preparation by using manual and rotary instrumentation techniques. J Endod 2012;38:1383-1386.

6. Yang G, Yuan G, Yun X, Zhou X, Liu B, Wu H. Effects of two nickeltitanium instrument systems, Mtwo versus ProTaper universal, on root canal geometry assessed by micro-computed tomography. J Endod 2011;37:1412-1416.

7. Almeida $M M$, Bernardineli $N$, Ordinola-Zapata $R$, Villas-Bôas $M H$, Amoroso-Silva PA, Brandão CG, et al. Micro-computed tomography analysis of the root canal anatomy and prevalence of oval canals in mandibular incisors. J Endod 2013;39:1529-1533.

8. Leoni GB, Versiani MA, Pécora JD, Sousa-Neto MD. Micro-computed tomographic analysis of the root canal morphology of mandibular incisors. J Endod 2014;40:710-716.

9. Ribeiro MVM, Silva-Sousa YT, Versiani MA, Lamira A, Steier L, Pécora JD, et al. Comparison of the cleaning efficacy of self-adjusting file and rotary systems in the apical third of oval-shaped canals. J Endod 2013;39:398-401.

10. Elayouti A, Chu AL, Kimionis I, Klein C, Weiger R, Löst C. Efficacy of rotary instruments with greater taper in preparing oval root canals. Int Endod J 2008;41:1088-1092.

11. Grande NM, Plotino G, Butti A, Messina F, Pameijer CH, Somma F. Crosssectional analysis of root canals prepared with NiTi rotary instruments and stainless steel reciprocating files. Oral Surg Oral Med Oral Pathol Oral Radiol Endod 2007;103:120-126.

12. Versiani MA, Pécora JD, Sousa-Neto MD. Flat-oval root canal preparation with self-adjusting file instrument: a micro-computed tomography study. J Endod 2011;37:1002-1007.

13. Rechenberg DK, Paqué F. Impact of cross-sectional root canal shape on filled canal volume and remaining root filling material after retreatment. Int Endod J 2013;46:547-555.

14. Neves MA, Rôças IN, Siqueira JF, Jr. Clinical antibacterial effectiveness of the self-adjusting file system. Int Endod J 2014;47:356-365.

15. Abramovitz I, Relles-Bonar S, Baransi B, Kfir A. The effectiveness of a self-adjusting file to remove residual gutta-percha after retreatment with rotary files. Int Endod J 2012;45:386-392.

16. Peters $\mathrm{OA}$, Peters $\mathrm{Cl}$, Schonenberger $\mathrm{K}$, Barbakow F. ProTaper rotary root canal preparation: effects of canal anatomy on final shape analysed by micro CT. Int Endod J 2003;36:86-92.

17. Paqué $F$, Balmer $M$, Attin T, Peters OA. Preparation of oval-shaped root canals in mandibular molars using nickel-titanium rotary instruments: a micro-computed tomography study. J Endod 2010;36:703-707.

18. Bürklein S, Hinschitza K, Dammaschke T, Schäfer E. Shaping ability and cleaning effectiveness of two single-file systems in severely curved root canals of extracted teeth: Reciproc and WaveOne versus Mtwo and ProTaper. Int Endod J 2012;45:449-461

19. Wu MK, van der Sluis LW, Wesselink PR. The capability of two hand instrumentation techniques to remove the inner layer of dentine in oval canals. Int Endod J 2003;36:218-224.

20. Ma J, Al-Ashaw AJ, Shen Y, Gao Y, Yang Y, Zhang C, et al. Efficacy of ProTaper Universal Rotary Retreatment system for gutta-percha removal from oval root canals: a micro-computed tomography study. J Endod 2012;38:1516-1520.

21. Wu MK, Wesselink PR. A primary observation on the preparation and obturation of oval canals. Int Endod J 2001;34:137-141.

22. Oliveira JC, Alves FR, Uzeda M, Rôças IN, Siqueira JF, Jr. Influence of serum and necrotic soft tissue on the antimicrobial effects of intracanal medicaments. Braz Dent J 2010;21:295-300.

23. Vera J, Siqueira JF, Jr., Ricucci D, Loghin S, Fernandez N, Flores B, et al. One-versus two-visit endodontic treatment of teeth with apical periodontitis: a histobacteriologic study. J Endod 2012;38:1040-1052.

24. Haapasalo M, Shen $Y$, Qian W, Gao Y. Irrigation in endodontics. Dent Clin North Am 2010;54:291-312. 